\title{
30 éves a Magyar Dietetikusok Országos Szövetsége
}

\section{The Hungarian Dietetic Association is 30 years old}

\section{Szerző:}

Kulcsszavak: dietetikus; táplálkozástudomány; MDOSZ; jubileum; konferencia

Keywords: dietitian; nutrition science; MDOSZ; anniversary; conference

Beküldve: 2021. 07. 27., doi: 10.24365/ef.v62i2.6875

Harminc éves jubileumát ünnepli idén a dietetikusok érdekvédelmi szakmai szervezete, a Magyar Dietetikusok Országos Szövetsége (MDOSZ). A közel 2000 főt számláló szövetség tagjai főiskolát végzett dietetikusok és egyetemet végzett táplálkozástudományi szakemberek, akik az egészségügy különböző területein túl az élelmezésvezetésben, a megelőzésben dolgoznak, valamint segítik az élelmiszeripari cégek munkáját is. A szövetség célja a lakosság egészségi állapotának javitása a helyes táplálkozás és életmód népszerűsítésével, az egészségmegőrző táplálkozási szokások kialakításának előmozdítása, valamint a táplálkozással összefüggő betegségek kezelésében való részvétel.

\section{A DIETETIKUSKÉPZÉS MÚLTJA}

Hazánkban a dietetikusok főiskolai képzése több mint negyvenöt éves múltra tekint vissza. A dietetikusi végzettséget négy év tanulás után lehet megszerezni a Semmelweis Egyetem Egészségtudományi Karán, a Pécsi Tudományegyetem Egészségtudományi Karán vagy a Debreceni Egyetem Népegészségügyi Karán. A diploma három területre ad jogosítványt: megelőzés, élelmezésvezetés és klinikai dietetika. A Magyar Dietetikusok Országos Szövetsége (MDOSZ) 1991-ben azért alakult meg, hogy képviselje és összefogja a dietetikus szakmát, továbbá ismereteiket a lakosság szolgálatába állítsa. Az MDOSZ tagja az Európai Dietetikusok Szövetségének (European Federation of the Associations of Dietitians, EFAD) és a Dietetikusok Világszövetségének (International Confederation of Dietetic Associations, ICDA) is.

\section{JUBILEUMI AKTIVITÁSOK}

A jubileum kapcsán a szövetség a Magyar Dietetikusok Országos Szövetsége - Terítéken az egészség Facebook oldalon közzétett, a szövetség történetét, $s$ a dietetikusok múködését ismertető posztokkal, videókkal, az okostanyer.hu oldalon hetente megjelenő, a szövetség vezetősége által javasolt receptekkel, valamint az MDOSZ honlapján is megjelenő friss hírekkel emlékezik meg az elmúlt 30 év eseményeiről. A havi rendszerességgel megjelenő Táplálkozás Akadémia Hírlevél is külön számban foglalkozik a dietetikus szakma, valamint a szövetség történetével.

\section{SZAKMAI KONFERENCIA}

2021. október 16-án, szombaton a Semmelweis Egyetem Markusovszky Dísztermében megrendezésre kerülő szakmai konferencia keretében a színvonalas előadások mellett jubileumi ünnepséggel is készül a kerek születésnap alkalmából. A konferencia tervezett programja a szövetség honlapján olvasható, a részvétel előzetes regisztrációt követően lehetséges. A szervezők 2021. október 5 -ig várják a jelentkezéseket a szabad helyek függvényében. Amennyiben a járványügyi helyzet nem teszi lehetővé személyes részvétellel történő konferencia megtartását, az esemény online kerül megrendezésre. 


\section{HIVATKOZÁSOK}

Magyar Dietetikusok Országos Szövetsége: A táplálkozáshoz szinte mindenki ért, pedig csak a dietetikusok! Szakmai szervezetük, a Magyar Dietetikusok Országos Szövetsége éppen 30 éves (Sajtóközlemény).

MDOSZ XXII. Szakmai Konferencia. "A ma kihívásai a táplálkozástudományban”. http://mdosz.hu/hun/wpcontent/uploads/2021/07/mdosz-konferencia-2021-program.pdf

Magyar Dietetikusok Országos Szövetsége: Táplálkozási Akadémia Hírlevél. 14. évfolyam, 6. szám - 2021. június. Dietetika: a táplálkozás tudománya és múvészete. http://mdosz.hu/hun/wp-content/uploads/2021/06/mdosztaplalkozasi-akademia-hirlevel-2021-06-dietetika-a-taplalkozas-tudomanya-es-muveszete.pdf

Információk a szerzőről

Schmidt Judit, vállalkozó dietetikus, a Magyar Dietetikusok Országos Szövetségének vezetőségi tagja, schjudit@gmail.com 